\title{
Pengaruh Spirulina terhadap VEGF dari Trofoblast Tikus Putih Hamil Strain Wistar yang Diinduksi Interleukin 6
}

\author{
Harry K Gondo ${ }^{1}$, Elizabeth Haryanti ${ }^{2 *}$ \\ SMF/Bagian Obstetri dan Ginekologi \\ Fakultas Kedokteran Universitas Wijaya Kusuma Surabaya ${ }^{1}$ \\ SMF/Bagian Ilmu Penyakit Dalam \\ Fakultas Kedokteran Universitas Wijaya Kusuma Surabaya ${ }^{2}$ \\ *e-mail: elizabeth@gmail.com
}

\begin{abstract}
Abstrak
Preeklampsia adalah gangguan kehamilan yang timbul akibat hipertensi. Preeklamsia terjadi dalam masa kehamilan yang ditandai dengan peningkatan proteinuria, tekanan darah serta interleukin 6. Spirulina $s p$ adalah ganggang berpigmen hijau-kebiruan yang memiliki bentuk seperti benang, seperti rangkaian sel berbentuk silindris dengan dinding sel berdiameter 1-12 $\mu \mathrm{m}$. Penelitian ini bertujuan untuk mengetahui pengaruh spirulina terhadap kadar VEGF dengan perbaikan fungsi trophoblast pada tikus putih hamil strain Wistar. Penelitian ini merupakan eksperimental laboratorik, dengan post test only control group design. Sebanyak 25 ekor tikus dengan model pre eklamsia diinduksi dengan interleukin 6, dibagi menjadi 5 kelompok yaitu kelompok kontrol, kelompok kontrol positif (PO) yang dinjeksi interleukin-6 dosis $5 \mathrm{ng} / 100$ gram Berat Badan (BB), kelompok pemberian spirulina dosis $10 \mathrm{mg} / 100$ gram BB (P1), kelompok (P2) pemberian spirulina dosis $20 \mathrm{mg} / 100$ gram BB, dan kelompok (P3) pemberian spirulina dosis $40 \mathrm{mg} / 100$ gram BB, kemudian diukur kadar Vascular endothelial growth factor (VEGF). Hasil penelitian ini dibandingkan dengan kadar VEGF dari kelompok kontrol. Kelompok (P1) pemberian spirulina dosis $10 \mathrm{mg}$ menunjukkan hasil rata-rata 81,31. Selanjutnya Kelompok P2 pada pemberian spirulina dosis $20 \mathrm{mg}$ didapatkan hasil yaitu 65,99 dan pemberian spirulina dosis $40 \mathrm{mg}$ dengan hasil 49,62. Jika dibandingkan terhadap kelompok kontrol dengan rata-rata kadar VEGF 62,70, maka spirulina dosis $20 \mathrm{mg}$ menunjukkan kadar VEGF yang mendekati kelompok kontrol.
\end{abstract}

Kata Kunci: Preeklamsia, spirulina, VEGF, Interleukin 6

\section{Effect of Spirulina on VEGF of Trophoblast Pregnant Wistar Rat Induced by Interleukin 6}

\begin{abstract}
Preeclampsia is a pregnancy disorder with hypertension as one of its common symptoms. Preeclampsia in pregnancy is characterized by increasing of proteinuria, blood pressure and also interleukin 6. Spirulina $s p$ is a thread like shaped blue-green algae, similar to chain of cylindrical cells with 1 to $12 \mu \mathrm{m}$ diameter of cell membrane. The purpose of this research was to know the effect of spirulina on VEGF level in improving of trophoblast function in pregnant white Rats Wistar. The design of the study was laboratory experimental with post-test only control group design. Twenty-five rats with preeclampsia model induced by interleukin 6 , were divided into 5 groups. The groups were control group, positive control group (PO) injected by interleukin-6 dose of $5 \mathrm{ng} / 100$ gram body weight (BW), group with spirulina dose of 10
\end{abstract}


Pengaruh Spirulina terhadap VEGF dari Trofoblast Tikus Putih Hamil Strain Wistar yang...

Harry K Gondo, Elizabeth Haryanti

$\mathrm{mg} / 100$ gram BW (P1), group with spirulina dose of $20 \mathrm{mg} / 100$ gram BW (P2); and group with spirulina dosage $40 \mathrm{mg} / 100 \mathrm{gram} B W(P 3)$. The Vascular endothelial growth factor (VEGF) levels were in experimental groups measured compared to control. The averages of group spirulina were 81.31 (10 mg/100 gram BW), 65.99 (20 mg/100 gram BW), and 49.62 (40 $\mathrm{mg} / 100$ gram BW). In comparison with control group (62.70), VEGF level in group administered by spirulina dose of $20 \mathrm{mg} / 100 \mathrm{gram} B W$ were close to control group.

Keywords: Preeclampsia, spirulina, VEGF, Interleukin 6

\section{PENDAHULUAN}

Kehamilan merupakan masa dimana terjadi perkembangan zigot di dalam rahim. Masa perkembangan zigot ini normalnya selama 36 minggu atau 9 bulan (Hill, 2012). Selama masa mengandung tersebut juga dapat memiliki resiko penyakit yang cukup berbahaya, salah satunya yaitu pre eklamsia. Pre eklamsia merupakan salah satu faktor pencetus penyebab terjadinya Angka Kematian Ibu (AKI) di berbagai negara termasuk Indonesia. Menurut data Indonesia Demographic and Health Survey (IDHS) pada tahun 2008-2012 AKI menunjukkan angka 359 per 100.000 kelahiran hidup (Achadi, 2019), sedangkan berdasarkan survey penduduk antar sensus (SUPAS) tahun 2015, angka kematian ibu di Indonesia periode 2011-2014 sebesar 305 yang artinya terdapat 305 kematian ibu karena kehamilan, persalinan sampai 42 hari setelah melahirkan pada periode 2011-2014 per 100.000 kelahiran hidup. (Badan Pusat Statistik, 2015). Angka tersebut masih jauh dari target yaitu dalam
Sustainable Development Goals (SDGs), pada tahun 2030 target AKI adalah 70 per 100.000 kelahiran hidup (Susiana, 2019).

Kenaikan tersebut direspon oleh Pemerintah melalui Kementerian Kesehatan Republik Indonesia dengan kerjasama USAID dengan mencanangkan program Expanding Maternal and Neonatal Survival (EMAS) pada tahun 2011 sampai 2017 yang diprioritaskan di kota atau kabupaten di enam provinsi dengan AKI diatas 50\% (Hyre et al, 2019). Angka Kematian Ibu bisa meningkat karena berbagai faktor seperti masalah gizi buruk, maupun penyakit yang diderita saat mengandung. Kematian pada ibu disebabkan beberapa faktor, yang berhubungan langsung adalah gangguan obstetrik antara lain preeklamsia atau eklamsia dan penyakkit atau infeksi yang diderita ibu sebelum atau selama kehamilan (Susiana, 2019).

Pada kondisi preeklamsia terjadi hipoksia atau kekurangan oksigen. Vaskular Endothelial Growth Factor (VEGF) diproduksi oleh plasenta dan menurun apabila plasenta kekurangan oksigen. VEGF 
Pengaruh Spirulina terhadap VEGF dari Trofoblast Tikus Putih Hamil Strain Wistar yang... Harry K Gondo, Elizabeth Haryanti

adalah mitogen sel endothelial yang potensial, bersifat proangiogenik dan mitogenik yang berperan sebagai vasodilator (Bhavina et al, 2014). Famili VEGF terdiri atas VEGF-A, VEGF-B, VEGF-C, VEGF-D, Placental Gowth Factor (PIGF), VEGF-E (Orf-VEGF), dan Trimeresurus flavoviridis SVVEGF (Shibuya, 2011). Pada kasus preeklamsia, VEGF akan diikat oleh Soluble fins-like tyrokinase-1 (sFlt-1) sehingga kadar VEGF bebas akan menurun (Sulistyowati et al, 2014).

Spirulina merupakan alga hijau biru dan termasuk dalam jenis cyanobacteria yang dapat dikonsumsi oleh manusia dan makhluk hidup lainnya. Awalnya Spirulina dipakai oleh bangsa Aztec, Maya dan berbagai suku lain di Amerika Latin. Mereka mengolah spirulina sebagai Tecuitlat/ seperti kue kecil yang berbahan dasar spirulina. Spirulina memiliki kandungan protein yang lengkap serta bersifat sebagai antioksidan yang baik bagi tubuh. Spirulina juga mengandung karotenoid, phycocyanin, beta-karoten, zeaxanthin, SOD, polisakarida, kalsium spirulan, GLA, vitamin B-12, vitamin K1 dan K2. Spirulina mengandung serat serta protein yang tinggi sehingga sangat baik untuk diet juga sebagai suplemen untuk menjaga kebugaran dan stamina (Moorhead and Capelli, 2012). Pada penelitian yang dilakukan oleh Castro-
Garcia et al (2018), pemberian phycobiliproteins dari spirulina dosis $100 \mathrm{mg} / \mathrm{kg} / \mathrm{hari}$ selama 3 minggu secara signifikan dapat menurunkan tekanan darah dan menstabilkan kembali kadar glukosa pada tikus yang preeklampsia. Spirulina juga mengandung antioksidan sehingga berguna untuk mencegah kanker.

Model preeklamsia pada tikus dapat dilakukan dengan induksi sitokin interleukin-6 (IL-6) selama kehamilan. Interleukin-6 adalah sitokin proinflamasi, yang ketika kadarnya meningkat akan menyebabkan peningkatan aktivasi inflamasi secara sistemik, pelepasan faktor vasokonstriksi, disfungsi endotel dan hipertensi yang smeuanya merupakan bagian dari sindroma preeklamsia (Raghupathy, 2013). Berdasarkan permasalahan tersebut, maka penelitian ini bertujuan untuk untuk melihat pengaruh spirulina terhadap VEGF dari trofoblas tikus putih hamil yang diinduksi IL-6.

\section{BAHAN DAN METODE}

Rancangan penelitian yang digunakan yaitu menggunakan rancangan penelitian Post Test Only Control Group Design. Dalam rancangan penelitian ini terbagi atas kelompok kontrol, kontrol positif (PO) dan tiga kelompok diberi perlakuan. 
ISSN 1978-2071 (Print); ISSN 2580-5967 (Online) Jurnal IImiah Kedokteran Wijaya Kusuma 9(2) : 123-130, September 2020

Kontrol $=$ kelompok kontrol normal, tikus diberikan minum dan aquades

PO = Kelompok kontrol model preeklamsia dengan induksi IL-6 dengan dosis $5 \mathrm{ng} / 100$ gram berat badan (BB) tikus (i.v)

$\mathrm{P} 1$ = Kelompok perlakuan IL 6 dosis $5 \mathrm{ng} / 100$ gram BB (i.v) dan spirulina dengan dosis $10 \mathrm{mg} / 100$ gram BB per hari

$\mathrm{P} 2$ = Kelompok perlakuan $\mathrm{IL} 6$ dosis 5ng/100 gram BB (i.v) dan spirulina dengan dosis $20 \mathrm{mg} / 100$ gram BB per hari

P3 = Kelompok perlakuan IL 6 dosis $5 \mathrm{ng} / 100$ gram BB (i.v) dan spirulina dengan dosis 40 mg/100 gram BB per hari

$\mathrm{O}=$ Observasi ekspresi VEGF dari jaringan tikus Wistar kelompok kontrol pada hari-14

O1 = Observasi ekspresi VEGF dari jaringan tikus Wistar kelompok PO pada hari-14

O2 = Observasi ekspresi VEGF dari jaringan tikus Wistar kelompok P2 pada hari14

O3 = Observasi ekspresi VEGF dari jaringan tikus Wistar kelompok P3 pada hari14

\section{Metode induksi preeklamsia}

Tikus betina dengan umur 2 sampai 3 bulan dan berat antara $150-250$ gram di pisahkan dengan tikus jantan selama dua minggu dengan tujuan agar menyeragamkan usia kehamilan tersebut. Setelah dua minggu tikus jantan dan betina dimasukkan sepasang dalam setiap kandang. Lalu dilakukan pemeriksaan setelah 1 malam apakah terdapat vaginal plug pada tikus betina. Tikus yang telah dinyatakan hamil akan di bagi menjadi 5 kelompok dengan setiap kelompok berisi lima tikus. Selama penelitian tikus diberikan makanan AIN 93 G dari Dyets Inc, dan minuman akuades secara libitum. (Kandungan AIN 93G: tepung 40\%, kasein $20 \%$, maltodextrin $13 \%$, Sukrosa $10 \%$, minyak kedelai $7 \%$, fiber $5 \%$, mineral mix 3,5\%, vitamin mix 1\%, L-cystine 0,3\%, choline bitartrate $0,25 \%$, Tertbutylhydroquinone $0,0014 \%$ ). Setelah masa adaptasi tikus dalam kelompok kontrol, P0, P1, P2, P3 akan disuntikkan IL-6 menggunakan wing needle pada vena ekor dengan dosis $5 \mathrm{ng} / 100$ gram BB selama tiga hari agar menjadi tikus dengan model patologis kehamilan. Spirulina pada masing-masing kelompok diberikan yaitu P1 dosis sebesar 10mg/ BB/ hari; P2 dengan dosis $20 \mathrm{mg} / \mathrm{BB} /$ hari; dan P3 dengan dosis $40 \mathrm{mg} / \mathrm{BB} / \mathrm{hari}$. Setelah perlakuan hewan coba, kelompok kontrol dan kelompok perlakuan diberikan dengan ketamin $0,5 \mathrm{mg}$ peroral. Setelah tikus pingsan akan dilakukan pembedahan untuk 
Pengaruh Spirulina terhadap VEGF dari Trofoblast Tikus Putih Hamil Strain Wistar yang... Harry K Gondo, Elizabeth Haryanti

mengambil plasenta dan diletakkan pada tabung effendorf berisi formalin $10 \%$. Plasenta akan dipotong dan ditempatkan pada objek glass yang telah diwarnai menggunakan metode imunofluorosense memakai antibodi polyclonal Bax dengan reagen pewarnaan FITC dan Rodamin. Pembacaan hasil dengan mikroskop Convocal.

\section{HASIL}

Tabel 1. Ekspresi VEGF setelah pemberian spirulina

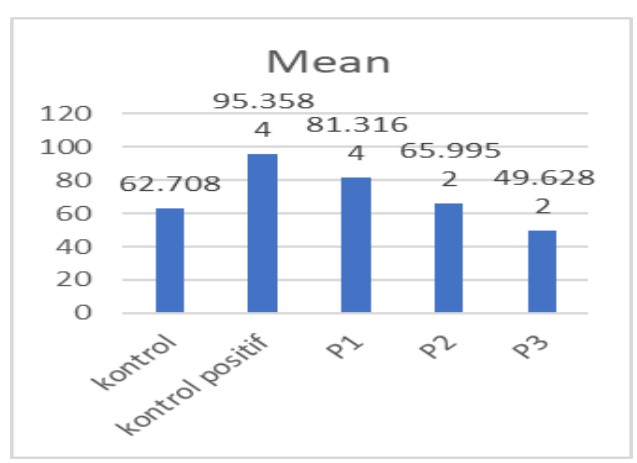

Keterangan: Kontrol positif (P0) diinjeksi IL-6 dosis 5ng/ 100 gram BB; P1; P2 dan P3 diberikan spirulina masing-masing dosis 10,20 dan $40 \mathrm{mg} / 100$ gram BB)

Pada tabel tersebut dapat dilihat ekspresi VEGF setelah pemberian spirulina pada kelompok P1, P2 dan P3. Kelompok P1 yang diberikan dosis spirulina $10 \mathrm{mg} /$ 100 gram BB/ hari; P2 diberikan dosis 20 mg/ 100 gram BB/ hari; dan P3 diberikan dosis 40 mg/ 100 gram BB/ hari. Data dari P1 didapatkan hasil 81,31, data dari P2 didapatkan hasil 65,99 dan P3 didapatakan hasil 49,63. Selanjutnya data hasil pengamatan dari kelompok P1, P2 dan P3 dibandingkan dengan kontrol. Data hasil penelitian dikatakan efektif apabila nilainya mendekati kontrol. Dalam penelitian ini data yang paling mendekati nilai kontrol yaitu P2.

Tabel 2. Grafik Pre-test (kiri) dan Post-test (Kanan) Tekanan darah dan Proteinuria sebelum diinduksi Interleukin-6.
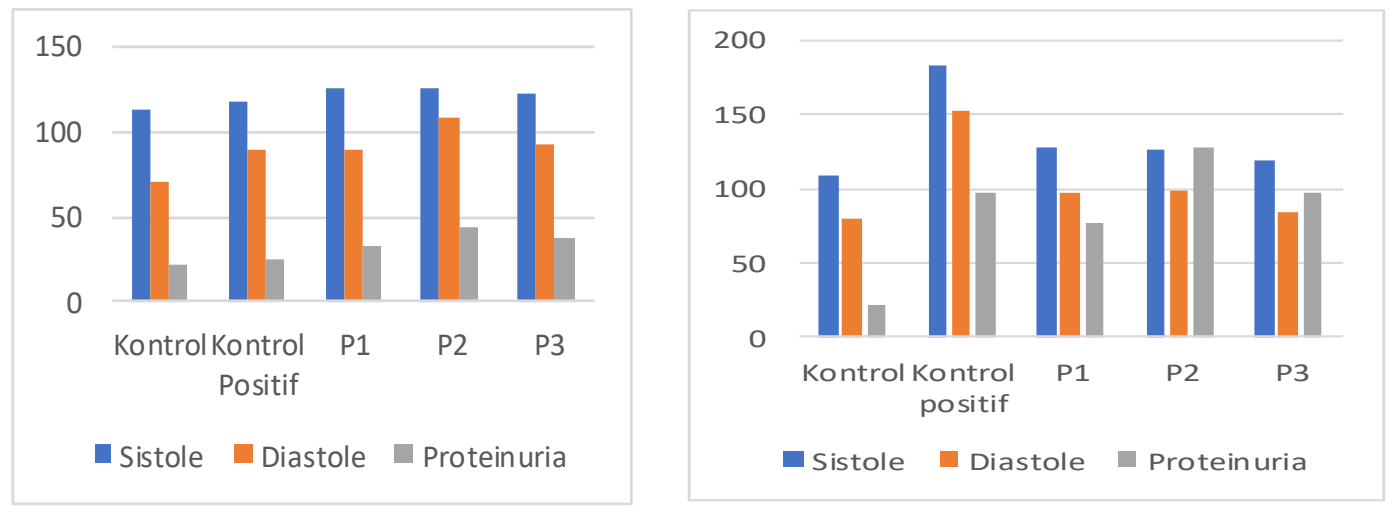

Keterangan: Kontrol positif (P0) diinjeksi IL-6 dosis 5ng/ 100 gram BB; P1; P2 dan P3 diberikan spirulina masing-masing dosis 10, 20 dan $40 \mathrm{mg} / 100$ gram BB) 

Dari data pada Tabel 2. dapat dilihat bahwa terjadi peningkatan terhadap tekanan darah sistole dan diastole dan proteinuria dari tikus yang telah diinjeksi dengan IL-6 dengan dosis 5ng/ 100 gram BB tikus (PO). Proteinuria dan tekanan darah karena merupakan gejala klinis dari pre eklamsia.

Tekanan darah pada kelompok kontrol adalah 113.6/ $71.6 \mathrm{mmHg}$ dan proteinuria 21,42 g/ dl. Pada kelompok kontrol positif (P0), rata-rata tekanan systole/ diastole sebelum diberi spirulina yaitu 117.6/ 89.8mmHg meningkat menjadi $184 / 152.4 \mathrm{mmHg}$ dan rata-rata proteinuria meningkat dari $25.7552 \mathrm{~g} / \mathrm{dl}$ menjadi 97.297 g/ dl. Pada kelompok P1 dengan pemberian spirulina dosis $10 \mathrm{mg} / 100 \mathrm{gram}$ $\mathrm{BB}$, rata-rata tekanan systole/ diastole juga meningkat dari 126.2/ $90.4 \mathrm{mmHg}$ menjadi 127.6/ $97 \mathrm{mmHg}$ dan rata-rata proteinuria meningkat dari $32.817 \mathrm{~g} / \mathrm{dl}$ menjadi 77.044 g/ dl. Pada kelompok P2 dengan pemberian spirulina $20 \mathrm{mg} / 100$ gram BB, tidak mengalami kenaikan rata-rata tekanan systole/ diastole yang signifikan dari 126.4/ $108.4 \mathrm{mmHg}$ menjadi 127/ $98.6 \mathrm{mmHg}$ dan rata-rata proteinuria mengalami peningkatan yaitu $43.68 \mathrm{~g} / \mathrm{dl}$ menjadi 127.92 g/ dl. Pada kelompok P3 yaitu kelompok dengan dosis spirulina 40 $\mathrm{mg} / 100$ gram $\mathrm{BB}$, terjadi peningkatan ratarata tekanan darah systole/ diastole yaitu
122.6/ 93.4 mmHg menjadi 119.8/ 84.4 $\mathrm{mmHg}$ dan rata-rata proteinuria meningkat dari $38.02 \mathrm{~g} / \mathrm{dl}$ menjadi $97.02 \mathrm{~g} / \mathrm{dl}$.

\section{PEMBAHASAN}

Pengaruh induksi IL-6 pada trofoblas tikus putih hamil dapat dilihat melalui peningkatan tekanan darah sistole dan diastole serta proteinuria. IL-6 merupakan sitokin pro-inflamasi. Peningkatan sitokin IL-6 juga sebagai penanda adanya inflamasi. Inflamasi ini juga dapat dilihat dari terjadinya apoptosis (Gondo, 2016). Pemberian injeksi IL-6 ternyata dapat menyebabkan inflamasi pada trofoblas. Pemberian IL-6 dengan dosis 5ng/100 gram BB tikus ternyata dapat menjadikannya preeklamsia. Preeklamsia yang terjadi juga akan diikuti dengan tanda-tanda klinis seperti tekanan darah dan proteinuria yang meningkat (Tabel 2). Kadar VEGF nya juga meningkat dikarenakan terjadinya hipoksia. Hipoksia pada kehamilan dapat terjadi, karena gagalnya remodeling arteri spiralis dan tidak optimalnya invasi trofoblas akibat dari gejala-gejala yang ditimbulkan oleh preeklamsia (Raghupathy, 2013).

Pengaruh pemberian spirulina terhadap aktivitas VEGF tikus putih hamil yang diinduksi IL-6 juga dapat diketahui melalui aktivitas VEGF menggunakan metode imunofluoresen. Spirulina merupakan alga hijau biru yang memiliki 
Pengaruh Spirulina terhadap VEGF dari Trofoblast Tikus Putih Hamil Strain Wistar yang... Harry K Gondo, Elizabeth Haryanti

bentuk silinder dengan sel berkolom membentuk filamen terpilin menyerupai spiral. Spirulina memiliki kandungan fikosianin yang tinggi (Moorhead, 2012).

Pada penelitian Romay et al (2003) menyatakan bahwa fikosianin dapat mengurangi efek radikal bebas dalam tubuh seperti alkoxyl, hydroxyl dan perokxyl serta mampu mengurangi efek inflamasi yang ditandai dengan menurunnya kadar TNF- $\alpha$ didalam tubuh tikus yang terpapar endotoksin dan mampu bersifat sebagai neuroprotektif pada jaringan otak tikus.

Hasil penelitian pada kelompok P1 menunjukkan hasil rata-rata 81,31 , pada kelompok P2 didapatkan hasil yaitu 65,99 dan kelompok P3 dengan hasil 49,62. Jika dibandingkan antar kelompok normal $(62,70)$, ekspresi VEGF pada kelompok P2 dosis $20 \mathrm{mg} / 100$ gram BB mendekati kelompok control normal.

Dosis efektif pemberian spirulina, pada penelitian ini adalah yang kelompok P2 yaitu pemberian spirulina $20 \mathrm{mg} / 100$ gram BB. Pada penelitian ini dosis ini juga efektif menurunkan kadar VEGF dibandingkan dengan kelompok P1 dan kelompok P3. Pada Penelitian ini, pemberian antioksidan dengan dosis yang terlalu rendah atau tinggi dapat mengubahnya menjadi radikal bebas. Pemberian spirulina pada kelompok P1 dan
P3 berdampak bagi uterus dan plasenta yang dapat dilihat melalui terjadinya penurunan pada VEGF dibandingkan dengan kelompok P2. Pada kelompok P3 terjadi penurunan ekspresi VRGF yang lebih besar dibandingkan dengan kelompok P2. Menurut penelitian dari Bhavina (2014) mengatakan jika kadar VEGF terlalu rendah maka plasenta akan mengalami hipoperfusi. Jika terjadi hipoferfusi, maka hal ini menjadi pencetus fase awal terjadinya hipoksia.

\section{KESIMPULAN}

Pemberian Spirulina selama 5 hari mampu menimbulkan perbaikan VEGF ditandai dengan menurunnya kadar VEGF terutama pada kelompok (P2) dosis $20 \mathrm{mg} /$ 100 gram berat badan tikus per hari. Pemberian IL-6 selama 3 hari dengan dosis $5 \mathrm{mg} / 100$ gram berat badan tikus mampu menimbulkan efek patologis preeklamsia yaitu adanya proteinuria dan peningkatan tekanan darah sistole dan diastole

\section{DAFTAR PUSTAKA}

Achadi EL, 2019. Kematian Maternal dan Neonatal di Indonesia. Rakernas 2019. Fakultas Kesehatan Masyarakat. Universitas Indonesia.

Badan Pusat Statistik, 2015. Tujuan Pembangunan Berkelanjutan. 
ISSN 1978-2071 (Print); ISSN 2580-5967 (Online) Jurnal IImiah Kedokteran Wijaya Kusuma 9(2) : 123-130, September 2020

https://www.bps.go.id/indikator/i ndikator/view data/0000/data/13 $\underline{49 / \operatorname{sdgs} 3 / 1}$

Bhavina K, Rhadika J., Pandian SS, 2014. VEGF and eNOS Expression in Umbilical Cord from Pregnancy Complicated by Hyertensive Disorder with Different Severity. BioMed Research International, 2014: 1-6.

Castro-Garcia SZ, Chamorro-Cevallos G, Quevedo-Corona L, McCarty MF and Bobadilla-Lugo RA, 2018. Beneficial effects of phycobiliproteins from Spirulina maxima in a preeclampsia model. Life Sci. 211: 17-24

Gondo HK, 2016. Efek Protektif Phycocyanin Terhadap

Preeklampsia Melalui Hambatan Jalur Inflamasi Stress Oksidatif Dan Apoptosis Sel Trofoblas. Universitas Brawijaya: Malang

Hyre A, Caiola N, Amelia D, Gandawidjaja T, Markus S et al, 2019. Expanding Maternal and Neonatal Survival in Indonesia: A Program Overview. Int J Gynecol Obstet, 144 (Suppl. 1): 7-12

Hill M, 2012. The Carniege Staged Embryos. Universitas New South Wales: Australia
Moorhead K and Capelli B, 2012. Spirulina Nature's Superfood. Cyanotech Corporation: Hawaii

Sulistyowati S, Roewendi A, Kartika H, Respati SH, 2014. Kadar Soluble Human Leukocyte Antigen-G (sHLA-G), Vascular Endothelial Growth Factor (VEGF), dan Soluble Fms-Like Tyrosine Kinase-I (sFlt-I) pada Preeklamsia. Majalah Obstetri \& Ginekologi. 22(3): 126131.

Raghupathy R, 2013. Cytokines as Key Players in the Pathophysiology of Preeclampsia. Med Princ Pract, 22(suppl 1): 8-19

Romay Ch, Gonzalez R, Ledon N, Remirez D, Rimbau V, 2003. CPhycocyanin: A Biliprotein with Antioxidant, Anti-Inflammatory and Neuroprotective Effects. Current Protein\& Peptide Science. $4(2): 207-216$

Shibuya M, 2011. Vascular Endothelial Growth Factor (VEGF) and Its Receptor (VEGFR) Signaling in Angiogenesis: A Crucial Target for Anti- and Pro- Angiogenic Therapies. Genes\& Cancer, 2(12): 1097-1106.

Susiana S, 2019. Angka Kematian Ibu: Faktor Penyebab dan Upaya Penanganannya. Bidang 
Pengaruh Spirulina terhadap VEGF dari Trofoblast Tikus Putih Hamil Strain Wistar yang... Harry K Gondo, Elizabeth Haryanti

Kesejahteraan Sosial Info Singkat.

11(24): $13-18$ 